\title{
Work Motivation Effect on State Civil Apparatus Performance during WFH with Discipline Variable
}

\author{
Icuk Rangga Bawono $^{1, a *}$, Erwin Setyadi ${ }^{1, b}$, Suhaila Abdul Hamid ${ }^{2, c}$ \\ ${ }^{1}$ Accounting Department, Faculty of Economics and Business, Universitas Jenderal Soedirman Purwokerto \\ Jl. H.R. Boenyamin No. 708, Grendeng, Purwokerto, Indonesia \\ ${ }^{2}$ Fakulti Ekonomi dan Muamalat, Universiti Sains Islam Malaysia \\ Bandar Baru Nilai, 71800, Nilai, Negeri Sembilan, MALAYSIA \\ e-mail: ${ }^{2 *}$ cukycutes@yahoo.com, ${ }^{\mathrm{b}}$ erwinsetyadi@gmail.com, ${ }^{\mathrm{c}}$ suhaila@usim.edu.my \\ * Corresponding Author
}

\begin{abstract}
Civil apparatus of the state should remain optimal in providing service to the community at the time of running work from home as a pandemic impact of Covid-19. Bureaucratic performance should also be maintained to ensure government programs can be directly perceived by the public. Governments are required to be able to apply flexible work patterns from two sides. That is flexible from the side of the work implementation, and flexible from the user side that in this case is the community. Despite working from home, the state civil apparatus is required to be able to provide optimal performance. This research seeks to see the motivation influence of state civil apparatus on their performance either directly or through disciplinary variables. Quantitative design has been adopted for this study using survey questionnaires prepared based on the Likert Scale (strongly disagree - 1 and 5 to strongly agree). The sample size consists of 100 state civil apparatuses and is processed using PLS. The results of this study concluded that direct motivation does not affect performance, but indirectly through discipline, motivation can influence a significant effect at the overall performance of civil apparatus of the state.
\end{abstract}

Keywords: COVID-19, Discipline, Motivation, Performance, Work from Home

Article History: Received: September, 42020 Revised: September, 302020 Accepted: October, 162020

How to cite: Bawono, I.R., Setyadi, E., \& Hamid, S.A. (2020). Work Motivation Effect on State Civil Apparatus Performance during WFH with Discipline Variable. Akrual: Jurnal Akuntansi, 11(2):110-121.

DOI: https://doi.org/10.26740/jaj.v11n2.p110-121

\section{INTRODUCTION}

The Covid-19 pandemic and global economic turmoil hit every aspect of life in the world community at once. This has an impact on the implementation of government programs in almost all over the world, including in Indonesia. Various community service strategies have been raised to overcome existing problems without reducing the quality of service to the public by the State Civil Apparatus, one of which is through work from home. Even though there are activity restrictions in the midst of the Covid-19 pandemic, the State Civil Apparatus is required to remain productive in providing services. Not only are they asked to remain disciplined in implementing health protocols, but the State Civil Apparatus must also be optimal in providing services to the community. The service of the state apparatus must continue to run even though they must apply health protocols by not meeting in 
person with with the people being served. The performance of the bureaucracy must also be maintained to ensure that government programs can be directly felt by the community. One of State Civil Apparatus efforts to maintain their performance in providing public services is through working from home (WFH).

The government needs to be able to apply flexible work patterns from two sides. This flexibility consists of flexible in terms of work application and flexible from the side of users, in this case, the community. If the parties strive to provide each other's flexibility instead of asking the other to provide more flexibility, more benefits will be discovered (Sushil, 2014). Flexibility of public services by government, especially during a pandemic by implementing Electronic Based Government System (SPBE).

The SPBE has to be implemented because most of the work is done through a network. The government provides several steps so that the State Civil Apparatus can work productively in the era of the Covid-19 pandemic. First, by distributing work locations as part of a flexible working arrangement. Second, rearranging a more flexible work process. Third, increasingly better service as services move online. Fourth, implementing more flexible working hours, either through a shift mechanism, or adjusted to service needs. Fifth, establishing a regulated workplace adhering to health protocols.

In terms of staffing, the government can create a flexible working culture and adopt flexible working methods, such as flexible time, flexible location, working from home, and training employees to be versatile. At the same time, employees can respond to changes in organizational needs by meeting urgent work requirements, making adjustments to the needs of the community, being more open and respecting the ideas of others, and even willing to fight for less compensation under unfavorable financial support (Sushil, 2014). Flexibility refers to the ability to sacrifice or change with minimal time, effort, cost or performance (Sushil, 1997). A flexibility does not means have to reduce quality. It eliminates rigidity in carrying out service activities so that people can be served optimally without having to go through the complicated and long bureaucracy. Another great flexibility relationship exists between government and society. The government provides services and receives various inputs from the community, and the community will in turn get services from the government that has high performance (Sushil, 2014). Whether the goverment effort is optimal or not can be seen from the performance of State Civil Apparatus.

Performance is needed to be measured to determine someone's ability to carry out their duties (Sunarsi, 2018). Employee performance is the condition or spirit that an employee has in doing his job (Liyas \& Primadi, 2017). Wibowo (2011) describes the performance as a result or work performance and how work goes. The work performance itself as a result of a specific job function or activity in a specific period (Bernardin \& Russel, 1993). This indicates that performance is the result of managing all physical and non-physical resources in personal or organizational work activities. In government agencies, performance appraisals are very useful for assessing the quantity, quality, and 
efficiency of services, motivating bureaucrats, and monitoring the government to pay more attention to the needs of the people it serves, and to guide improvements in public services.

In terms of providing and improve optimal service to the community, the State Civil Apparatus is required to have high work motivation even though they work from home. Victor H. Vroom expressed an expectation theory in the 1960s that if workers believe that hard work will bring high performance, then the motivation will be high, and high performance will bring the expected results. Work flexibility related to the Covid-19 pandemic through the implementation of work from home really requires high motivation from the State Civil Apparatus in carrying out their obligations. Without work motivation, people will become victims of the existing conditions. Motivation is formed by the attitude of employees in handling work situations. McClelland (McClelland, 1985) argues that motivation is a condition that drives employees to achieve organizational or work goal. According to Robbins (2009), Motivation is a process that can explain the strength, direction and perseverance of an individual to achieve a goal. According to Uno (2014), motivation can be interpreted as a person's inner and outer encouragement, which is expressed by the existence of desire and interest, encouragement and need, hope and ideal, appreciation and respect. Attitudes and values are the power that encourages individuals to take action to achieve their goals. Motivation is needed since it is human nature that requires some kinds of stimulation, encouragement and incentives to get better performance. Motivation is a technique to improve the performance of employees at different levels. Bao (2015), in his research results, Point out that all selected factors have a significant relationship with motivation and have a significant impact on performance. This fits with the results of Mohamud's (2017) research point out that employee motivation is positively related to employee performance.

Work motivation will encourage employees to have a high sense of discipline. Cairo explain discipline is about harwork (Cairo, 2002)._Meanwhile John Macquarrie (2001) defines discipline as a person's willingness and actions in obeying all the rules that have been arranged with a specific purpose. In another perspective, Ipong explain discipline as obedient on values and regulations to create "harmony" with "fairness" in every aspect of organization's life (Dekawati et al., 2019). Discipline is an attitude or behavior that is certainly expected by many people, especially educated ones because it can help an activity run smoothly as expected.

High performance can be created from high work motivation which leads to high disciplinary attitudes. Endang and Sari (Endang \& Sari, 2019) in Their research concluded that motivation and discipline have a major impact on performance. Motivation of someone could contribute to discipline to do their duties (Elvasusanti et al., 2019). Meanwhile research by Idris (2018) concluded that discipline has a significant effect on performance. This means there is a link between motivation and discipline that moves a person and can affect performance. This is because employees realize that motivation alone is not enough to improve performance. A different perspective shows by Kurniawan 
and Heryanto (2019) which states that discipline has no effect on performance. However, it supports the results which state that Motivation has a major impact on performance.

From the description above, the purpose of this study was investigate the direct relationship between work motivation and the performance of civil apparatus during the Covid-19 pandemic. This research also aims to treat the indirect relationship between work motivation and performance as an intermediate variable through work discipline.

\section{Research Model}

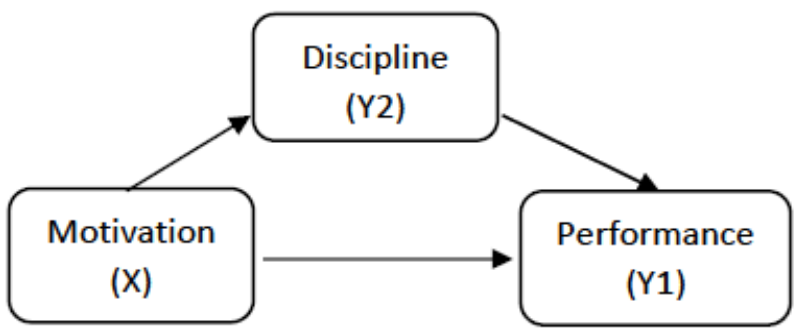

Figure 1. Research Model

\section{RESEARCH METHOD}

This study uses a quantitative method because it is presented in the form of data. This is in accordance with the opinion of Bryman (2017) which states that the quantitative research process starts from theory, hypothesis, research design, selecting subjects, collecting data, processing data, analyzing data, and writing conclusions.

\section{Research Population and Sample}

In this study, the population is all State Civil Apparatus who carry out WFH as a result of the Covid-19 pandemic. State Civil Apparatus used as sample who carried out WFH because of the Covid-19 pandemic situation obtained by random sampling methods in several regions in Indonesia.

\section{Data collection technique}

The data used in this study are primary data. Hanke and Reitsch (1989) define primary data as data obtained by field surveys using all original data collection methods. In this study, primary data were obtained from the results of a questionnaire given by researchers to the State Civil Apparatus who became the research sample. The questionnaire used is a replication and development of previous studies that have been adapted to the conditions based on the research theme.

The scale used in this study is the Likert scale. The Likert scale is used to measure the attitudes, opinions and opinions of a person or group of people on social phenomena In this study, the researchers specifically identified this social phenomenon, which is hereinafter referred to as research variable. Use Likert scale to convert the variable to be measured into variable index. Then the indicators are used as a starting point for arranging 
instrument items in the form of statements or questions. The Likert scale used in the answers for each instrument ranges from positive to negative and can be expressed in the form of words, namely:
1. Strongly Agree
: Score 5
2. Agree
: Score 4
3. Doubt
: Score 3
4. Disagree
: Score 2
5. Strongly Disagree
: Score 1

\section{Data Analysis Technique}

The analysis technique used to process the data of this study is based on the structural equation modeling (SEM) analysis of variance, namely partial least squares (PLS). Operational Variables

Table 1. Operational Variables and Research Indicators

\begin{tabular}{|c|c|c|}
\hline Variables & Dimension & Indicators \\
\hline \multirow[t]{3}{*}{ Motivation (X1) } & 1. Responsibility & $\begin{array}{l}\text { 1. Having a high sense of responsibility } \\
\text { in completing work }\end{array}$ \\
\hline & 2. Work Spirit & 2. Having passion at work \\
\hline & 3. Self Actualization & $\begin{array}{l}\text { 3. Willing to achieve maximum } \\
\text { performance at }\end{array}$ \\
\hline \multirow[t]{7}{*}{ Performance(Y1) } & 1. Quality & 1. Ability \\
\hline & & 2. Skills \\
\hline & & 3. Work result \\
\hline & 2. Quantity & 4. The quantity of work targeted \\
\hline & 3. Effectiveness & $\begin{array}{l}\text { 5. Effectiveness and efficiency in doing } \\
\text { work }\end{array}$ \\
\hline & & $\begin{array}{l}\text { 6. The level of solidarity in cooperation } \\
\text { among parts with WFH conditions }\end{array}$ \\
\hline & 4. Independence & $\begin{array}{l}\text { 7. Level of independence in completing } \\
\text { work at WFH }\end{array}$ \\
\hline \multirow[t]{2}{*}{ Discipline (Y2) } & 1. Obey & 1. Attitude obedience to work rules \\
\hline & 2. On Time & 2. Time at work \\
\hline
\end{tabular}




\section{RESULTS AND DISCUSSION}

\section{Structural Model Design (inner model)}

The design of the structural model of the relationship between the latent variables in PLS is based on the formulation of the problem or research hypothesis. In this study, the structural model of the relationship between variables is designed as follows:

1) Motivation becomes an exogenous variable

2) Performance becomes an endogenous variable 1

3) Discipline becomes an endogenous variable 2

\section{Designing the Measurement Model (outer model)}

The description of latent variables and their list variables is as follows:

1) Exogenous latent variables of motivation have three manifest variables which become reflective indicators, namely responsibility, morale and self-actualization.

2) Endogenous latent variable 1 performance has four manifest variables that are reflective indicators, namely quality, quantity, effectiveness and independence.

3) Endogenous 2 discipline latent variables have two manifest variables that become reflective indicators, namely obedience and timeliness.

\section{Path Diagram Construction}

The path diagram in accordance with this research is as follows:

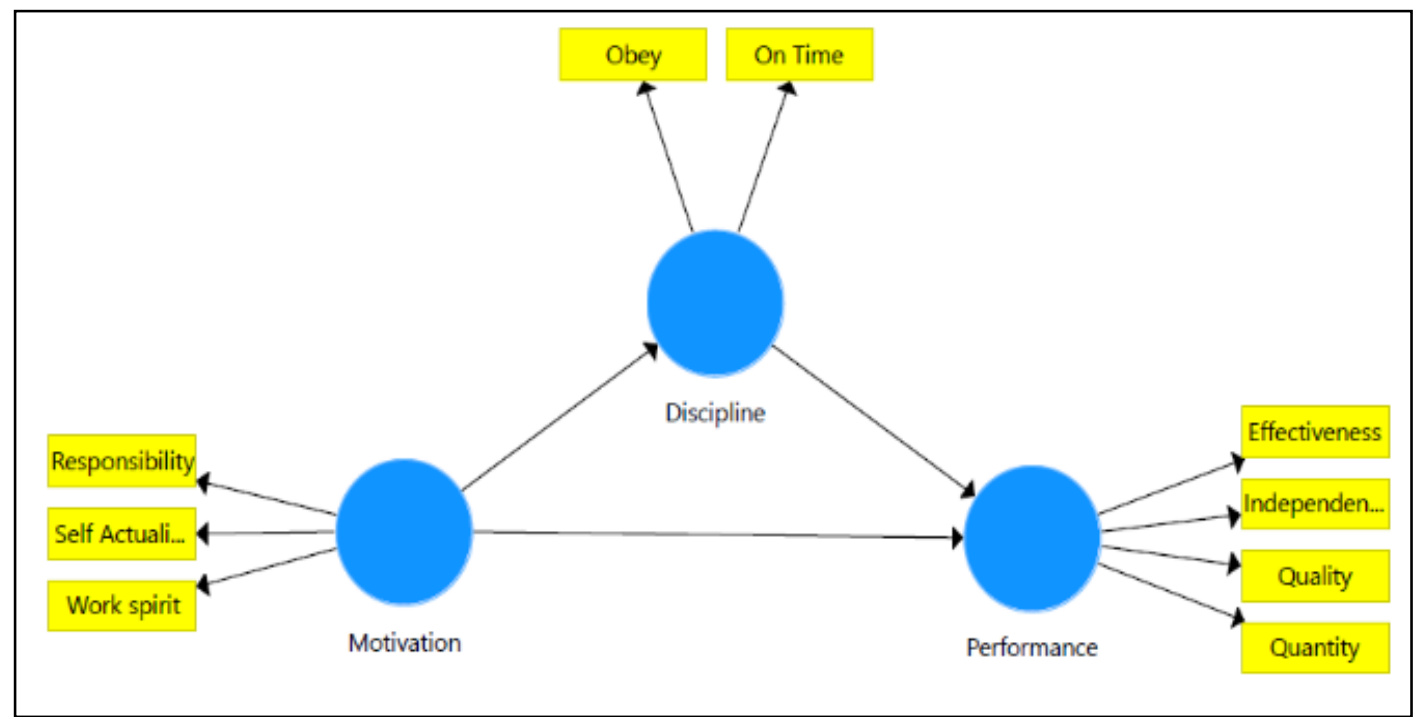

Figure 2. Path Diagram

\section{Evaluation of Measurement Model (Outer Model)}

\section{Convergent Validity Test}

The validity test of the reflection index can be done by using the correlation between the index score and the construction score. The calculation results using PLS are as follows: 
Table 2. Outer loading output

\begin{tabular}{lrrr}
\hline & Discipline & Motivation & performance \\
\hline Obey & 0.980 & & \\
on time & 0.980 & & \\
responsibility & & 0.895 & \\
self actualization & & 0.868 & \\
work spirit & 0.913 & 0.822 \\
effectiveness & & 0.858 \\
Quality & & 0.876 \\
quantity & & 0.880 \\
independence & &
\end{tabular}

If the associated loading value is greater than 0.5 , the convergence validity can be satisfied. The output shows that the value given by the loading factor is $>0.5$. Therefore, the indicators used in this study have reached convergence validity.

Discriminant Validity Test

If the indicator has the highest load factor value compared to the expected structure's load factor value, the indicator is declared valid.

Table 3. Cross loading output (discriminant validity)

\begin{tabular}{lrrr}
\hline \multicolumn{2}{c}{ Discipline } & motivation & performance \\
\hline obey & 0.980 & 0.816 & 0.772 \\
on time & 0.980 & 0.725 & 0.848 \\
responsibility & 0.761 & 0.895 & 0.770 \\
self actualization & 0.673 & 0.868 & 0.532 \\
work spirit & 0.660 & 0.913 & 0.635 \\
effectiveness & 0.579 & 0.486 & 0.822 \\
quality & 0.754 & 0.843 & 0.858 \\
quantity & 0.720 & 0.584 & 0.876 \\
independence & 0.761 & 0.561 & 0.880 \\
\hline Source : Primary data are processed, 2020 & &
\end{tabular}

It can be seen from the above table that the load factor value of each index has the highest value for the expected construct compared with the load factor values of other constructs. Therefore, the indicators used in this study have reached discriminative validity.

\section{Reliability Test}

The latent variable has good reliability.if the composite reliability value is greater than 0.7 and Cronbach's alpha value is greater than 0.7. 
Table 4. Reliability Test

\begin{tabular}{lrrrr}
\hline & $\begin{array}{l}\text { Cronbach's } \\
\text { Alpha }\end{array}$ & Rho_A & $\begin{array}{l}\text { Composite } \\
\text { reliability }\end{array}$ & AVE \\
\hline discipline & 0.958 & 0.958 & 0.980 & 0.960 \\
motivation & 0.873 & 0.885 & 0.921 & 0.796 \\
performane & 0.882 & 0.892 & 0.919 & 0.738 \\
\hline Source : Primary data are processed, 2020 & & &
\end{tabular}

Table 4 shows that all latent variables used in this study have Cronbach's Alpha and Composite Reliability values $>0.7$. Therefore, it is said that all latent variables are reliable.

\section{Evaluation of the Structural Model (Inner Model)}

$R$-square Test

The R-squared value is used to measure the variability level of the independent variable on the dependent variable. The change in $\mathrm{R}$-squared value $\left(\mathrm{R}^{2}\right)$ is used to evaluate the influence of certain independent variables on the dependent variable. Use PLS to obtain the output value of $\mathrm{R}^{2}$ as follows:

Table 5. R-Square output

\begin{tabular}{llrr}
\hline & R-Square & & R-Square Adjusted \\
\hline discipline & & 0.619 & 0.615 \\
performance & 0.702 & 0.696 \\
\hline
\end{tabular}

Source : Primary data are processed, 2020

The R-square value of 0.619 in the discipline shows that $61.9 \%$ of the discipline of the State Civil Apparatus is influenced by motivation and the R-square value of 0.702 on performance shows that $70.2 \%$ of the performance of the State Civil Apparatus is influenced by motivation. The rest is affected by other variables not measured in this study.

Significance Test

Use the PLS SEM method to conduct hypothesis testing through the bootstrap process to obtain the relationship between the influence of exogenous variables on endogenous variables, as shown below:

Table 6. Significance Test

\begin{tabular}{|c|c|c|c|c|c|}
\hline & $\begin{array}{l}\text { Original } \\
\text { sample }\end{array}$ & $\begin{array}{l}\text { Sample } \\
\text { mean }\end{array}$ & $\begin{array}{l}\text { Standard } \\
\text { deviation }\end{array}$ & T-Statistics & P Value \\
\hline discipline $\rightarrow$ performance & 0.655 & 0.623 & 0.124 & 5.279 & 0.000 \\
\hline motivat & 0.787 & 0.784 & 0.047 & 16.645 & 0.000 \\
\hline motivation $\rightarrow$ performance & 0.219 & 0.255 & 0.147 & 1.485 & 0.138 \\
\hline
\end{tabular}

Source : Primary data are processed, 2020 


\section{Hypothesis Test}

The $\mathrm{P}$ value of the confidence level is 95\% ( $\alpha$ is 5\%). The hypothesis test for the relationship of each latent variable is as follows:

a. First Hypothesis

The statistical hypothesis to be tested is:

Ho: Work motivation has no significant impact on the performance of State Civil Apparaturs.

Ha: Work motivation has a major impact on the performance of State Civil Apparatus.

Testing criteria:

a) If $P$ value or the significance value of more than tolerate errors $(\alpha=0.05)$, Ho is accepted. This means work motivation variable has no significant impact on the performance of States Civil Apparatus in Covid-19 pandemic situation.

b) If $P$ value or the significance value less than tolerate errors $(\alpha=0.05)$, then Ho is rejected or $\mathrm{Ha}$ is accepted. This means work motivation has a significant impact on the performance of States Civil Servants in Covid-19 pandemic situation.

According to the result significance test in Table 6, the $\mathrm{P}$ value for the motivation variable $(\mathrm{X})$ on the performance variable (Y1) is 0.138 more than tolerate errors $(\alpha=0.05)$. It can be concluded first hypothesis in this study rejected. That is, in this study motivation $(\mathrm{X})$ does not have a significant effect on the latent variable of State Civil Apparatus performance (Y1) with its indicators.

b. Second Hypothesis

The statistical hypothesis to be tested is:

Ho: Work motivation indirectly has no significant effect on performance through the discipline of the State Civil Apparatus.

Ha: Work motivation indirectly has a significant effect on performance through discipline of the State Civil Apparatus.

Testing criteria:

a) If $t$ count $<t$ table or the significance value of t the tolerable error percentage is (0.05), then Ho is accepted. This means that work motivation indirectly has no significant effect on State Civil Apparatus performance through the discipline of the State Civil Apparatus in the Covid-19 pandemic situation.

b) If $t$ count $>t$ table or the significance value of $t$ is the percentage of tolerable value is (0.05), then, Ho is rejected or $\mathrm{Ha}$ is accepted. This means work motivation indirectly has a significant effect on performance through the discipline of the State Civil Apparatus in Covid-19 pandemic situation.

The indirect effect test of motivation on performance through discipline is carried out by calculating the Sobel formula. According to Table 6, it is seen that the path coefficient and standard deviation of the relationship between motivation and discipline (a) and the relationship between discipline and performance (b) are as follows:

Table 7. Path Coefficient and Standard Deviation

\begin{tabular}{lclc}
\hline \multicolumn{1}{c}{ motivation $\rightarrow$ discipline } & \multicolumn{1}{c}{ discipline $\rightarrow$ performance } \\
\hline a & 0.787 & $\mathrm{~B}$ & 0.655 \\
Stdev a (Sa) & 0.047 & Stdev b $(\mathrm{Sb})$ & 0.124 \\
\hline \multicolumn{2}{l}{ Source $:$ Primary data are processed, 2020} &
\end{tabular}


The number of indirect coefficients of motivational variables in performance is the multiplication effect of motivation on discipline (a) and the effect of discipline on performance (b), which can be seen as follows:

$$
\begin{aligned}
\mathrm{Ab} & =\mathrm{a} \times \mathrm{b} \\
& =0.787 \times 0.655=0.0515485
\end{aligned}
$$

The amount of the indirect standard error of the motivation variable on performance is the multiplication of motivation towards discipline (a) and discipline towards performance (b), which can be seen as follows:

$$
\begin{aligned}
\mathrm{Sab} & =\sqrt{ } \mathrm{b}^{2} \mathrm{Sa}^{2}+\mathrm{a}^{2} \mathrm{Sb}^{2}+\mathrm{Sa}^{2} \mathrm{Sb}^{2} \\
& =\sqrt{ }(0.655)^{2}(0.047)^{2}+(0.787)^{2}(0.124)^{2}+(0.047)^{2}(0.124)^{2} \\
& =0.011004
\end{aligned}
$$

The $t$ value can be obtained by the following formula:

$\mathrm{t}=\mathrm{Ab} / \mathrm{Sab}$

$=0,0515485 / 0,011004=4,6845$.

$\mathrm{t}$ count is obtained for the motivation variable on the performance of 4.6845>t-table (1.661). By looking at $t$ count $>t$ table, it can be interpreted that Motivation has a major impact on performance through discipline. Therefore, the second hypothesis of this research is accepted.

\section{Discussion}

The result show that motivation doesn't has significant effect toward state civil apparatus during Covid-19 pandemic situation. This study not in line with the results of Mohamud's (2017) that point out employee motivation is positively related to employee performance. But this study support result of Inaray et al. (2016) that also show same result as this study. Eventhough motivation not significant to States Civil Apparatus during Covid-19 pandemic situation, motivation needed by every workers since it is human nature that requires stimulation, encouragement and incentives to get better performance in reality.

The result of this study show there's a link between motivation and performance of States Civil Apparatus through discipline variable. Endang and Sari (2019) explain that motivation and discipline have a major impact on performance. Motivation of someone could contribute to discipline to do their duties (Elvasusanti et al., 2019)._Meanwhile research by Idris (2018) concluded that discipline has a significant effect on performance. So, there's indirect relationship between work motivation and work performance through discipline. Higher work motivation would drive discipline of states civil apparatus work performance during Covid-19 pandemic situation. When each States Civil Apparatus have high discipline and dedication to their job it would raise up their performance. Covid-19 pandemic situatuan force everybody including States Civil Aparatus to do WFH for served society. Motivation alone is not enough to maintain work performance in this situation, with combining discipline attitude to handling work situation, the performance of the state civil apparatus will be maintained. 


\section{CONCLUSION}

The results of the research on the effect of work motivation on the performance of State Civil Apparatus at work from home during the Covid 19 pandemic with work discipline as an intervening variable show the following:

1. Due to the impact of the Covid-19 pandemic, work motivation has no significant impact on the performance of national civil servants, and the performance of working from home.

2. Motivation indirectly has a significant impact on performance through discipline of the State Civil Apparatus when carrying out work from home during the Covid-19 pandemic.

Based on the completed research results, the authors provide the following suggestions:

1. Discipline is one of the important things in the era of the Covid-19 pandemic with a work pattern that prioritizes flexibility in terms of time, place and work flow. Supervision of the level of discipline needs to be the main focus of the leadership to maintain the quality of service to the community.

2. Efforts to maintain the work motivation of the State Civil Apparatus should be carried out continuously, especially those affecting the level of discipline of the officials so that work motivation that can increase discipline will be able to have a positive effect on improving performance.

\section{REFERENCES}

Bao, C., \& Nizam, D. I. (2015). The Impact Of Motivation On Employee Performance In The Electronics Industry In China. International Journal of Accounting and Business Management. https://doi.org/10.24924/ijabm/2015.11/v3.iss2/29.45

Bernardin, H. J., \& Russel, J. E. . (1993). Human Resourses management. New York: Mc Graw Hill Inc.

Bryman, A., \& Bell, E. (2017). Business Research Methodology. Research Methodology.

Cairo, C. (2002). Motivasi dan Strategi Menentukan Tujuan Hidup dan Karir Anda. Prestasi Pustaka.

Dekawati, I., Suhendar, D., \& Aji, A. I. (2019). Organizational Behavior and Work Disciplines (Their Effect on Work Achievement). https://doi.org/10.2991/icream18.2019 .78

Elvasusanti, E., Syamsudduha, S., \& Rahman, U. (2019). The Effect of Madrasah Head Leadership Style and Work Motivation on Work Discipline of Madrasah Aliyah Teachers. Jurnal Ilmiah Ilmu Administrasi Publik. https://doi.org/10.26858/jiap.v9i1.9312

Endang, T., \& Sari, E. (2019). The Effect Of Motivation And Discipline On Employee Performance At The Ministry Of Transportation's Directorate Of Ports. Ilomata International Journal of Social Science. https://doi.org/10.26858/pdr.v2i1.13235 
Idris, M. (2018). The Impact of Education and Training, Work Discipline and Organizational Culture on Employee's Performance: The Study of Disaster Management and Fire Department in Palembang City, Indonesia. International Journal of Human Resource Studies, 8(3), 1. https://doi.org/10.5296/ijhrs.v8i3.13013

Inaray, J. C., Nelwan, O. S., \& Lengkong, V. P. K. (2016). Pengaruh Kepemimpinan dan Motivasi Kerja terhadap Kinerja Karyawan pada PT. Amanah Finance di Manado. Jurnal Berkala Ilmiah Efisiensi, 16(2), 459-470.

Iyer, R., Hanke, J. E., \& Reitsch, A. G. (1989). Business Forecasting. The Statistician. https://doi.org/10.2307/2349022

Kurniawan, Harry, H. (2019). Effect of Work Discipline and Work Environment on Employee Performance with Work Motivation as an Intervening Variable in Department of Tourism, Youth and Sport of Padang District. Archives of Business Research, 7(7), 88-101.

Liyas, J. N., \& Primadi, R. (2017). Pengaruh disiplin kerja terhadap kinerja karyawan pada bank perkreditan rakyat. Al Masraf: Jurnal Lembaga Keuangan Dan Perbankan. https://doi.org/10.1016/j.nanoen.2012.08.008

Macquarrie, J. (2001). Postmodernism in philosophy of religion and theology. International Journal for Philosophy of Religion. https://doi.org/10.1007/978-94-0100516-6_2

McClelland, D. C. (1985). How motives, skills, and values determine what people do. American Psychologist. https://doi.org/10.1037//0003-066x.40.7.812

Mohamud, S. A., Ibrahim, A. A., \& Hussein, J. M. (2017). The effect of motivation on employee performance: Case study in Hormuud company in Mogadishu Somalia. International Journal of Development Research.

Robbins, S., \& Judge, T. (2009). Organizational Behaviour: Concepts, Controversies, Applications. In Development.

Sunarsi, D. (2018). Pengaruh Gaya Kepemimpinan, Motivasi dan Disiplin Kerja terhadap Kinerja Pendidik Yayasan Marvin. https://doi.org/10.32493/inovasi.v5i1.y2018.p1-18

Sushil. (2014). Duality of enterprise and stakeholders on flexibility front. Global Journal of Flexible Systems Management, 15(3), 179-180. https://doi.org/10.1007/s40171014-0072-y

Sushil, P. (1997). Flexible systems management: An evolving paradigm. Systems Research and Behavioral Science, 14(4), 259-275. https://doi.org/10.1002/(sici)10991743(199707/08)14:4<259::aid-sres159>3.0.co;2-1

Uno, B. H. (2014). Teori Motivasi \& Pengukurannya. Personnel Review.

Weiner, B. (1985). An Attributional Theory of Achievement Motivation and Emotion. Psychological Review. https://doi.org/10.1037/0033-295X.92.4.548

Wibowo. (2011). Manajemen Kinerja. In Raja Grafindo Persada. 